Saudi Journal of Business and Management Studies Abbreviated Key Title: Saudi J Bus Manag Stud ISSN 2415-6663 (Print) IISSN 2415-6671 (Online) Scholars Middle East Publishers, Dubai, United Arab Emirates Journal homepage: https://saudijournals.com/sibms

Review Article

\title{
The Implementation of Human Resource Management in Organized Retail
}

\author{
Mutaz Minwer Halal Alharbi ${ }^{1}$, Dr. Amgad S. Khaled ${ }^{2 *}$ \\ ${ }^{1}$ Assistant Professor Faculty of Administrative and Financial Science Irbid National University Amman, Jordan \\ ${ }^{2}$ Department of Business Administration Aligarh Muslim University Uttar Pradesh India
}

DOI: $\underline{10.36348 / \mathrm{sjbms} .2020 . \mathrm{v} 05 \mathrm{i} 04.003}$

| Received: 06.03.2020 | Accepted: 13.03.2020 | Published: 29.04.2020

*Corresponding author: Amgad S. Khaled

\section{Abstract}

An organisation's success depends heavily on its Human Resource. Human Resource Management (HRM) plays an important role in accomplishing the organizational targets. With massive contribution to Indian economic system, the retail industry has performed an incredible role in India. With the arrival of large retail businesses, the retailing industry experienced enormous changes. Organized retailing is undergoing a metamorphosis in India and is expected to increase to meet global standards. The need for successful HRM activities has increased rapidly in this world of cut throat competition. HRM operations have now become their primary concern. The paper before us is an effort to examine the HRM activities adopted in India's structured retail sector. The report also sheds light on the difficulties faced by the industry by Human Resource (HR), and recommended steps to improve the Indian scene working culture.

Keywords: HRM, HR obstacles, Retail Industry, HRM Practice and Organized Retailing.

Copyright @ 2020: This is an open-access article distributed under the terms of the Creative Commons Attribution license which permits unrestricted use, distribution, and reproduction in any medium for non-commercial use (NonCommercial, or CC-BY-NC) provided the original author and source are credited.

\section{INTRODUCTION}

Human Resource Management (HRM) is the organisational feature that addresses people-related issues like administration, compensation, training, hiring, talent management, security, advantages, motivation of employees and interaction. HRM is a systematic and detailed approach to workforce management (Heathfield, n.d.). With growth in many sectors in the present globalised world era, its role in the success of the business is growing fast. The HRM activities are essential in manpower staffing, performance assessment, remuneration, and learning and development system design. Innovative HRM strategies can be influential in transforming employee behaviors. In the current scenario, the HRM activities in the service industry particularly in the retail industry have found significant importance. Retailing is one of the service industries where high expectations are set for the need for qualitative staff resources [1]. Therefore, the current paper discusses on the HRM activities in India's structured retail sector and illustrated the industry's existing HR obstacles. Part I provides an overview of retail sector in India. Therefore, the current paper discusses on the HRM activities in India's structured retail sector and illustrated the industry's existing HR obstacles. Part I provides an overview of retail sector in India. The Administration of Human Resource in the organized retail revealed in Part II. Part III highlights the HR problems the organized Indian retail sector is facing. Phase IV presents the concept and recommendations. This study aims to:

- Review the current condition of the Indian retail sector.

- examine the human resources management practices adopted in India's organized retail sector

- $\quad$ survey the HR obstacles organized sellers face during the implementation of these practices

\section{Indian retail scenario}

Table-1: Type of Retail

\begin{tabular}{|l|r|}
\hline Sector & percentage \\
\hline Organized & 8 \\
\hline Unorganized & 92 \\
\hline
\end{tabular}


The Indian retail sector is typically classified into organized and unorganized retailers. Fig. 1 and table 1 indicates that India accounts for only $8 \%$ of the organized retail sector and the remaining $92 \%$ remain unorganized and, throughout the organized market, clothing is the largest demographic, while nutrition and grocery and internet and telecommunications were the other significant contributors towards this group.

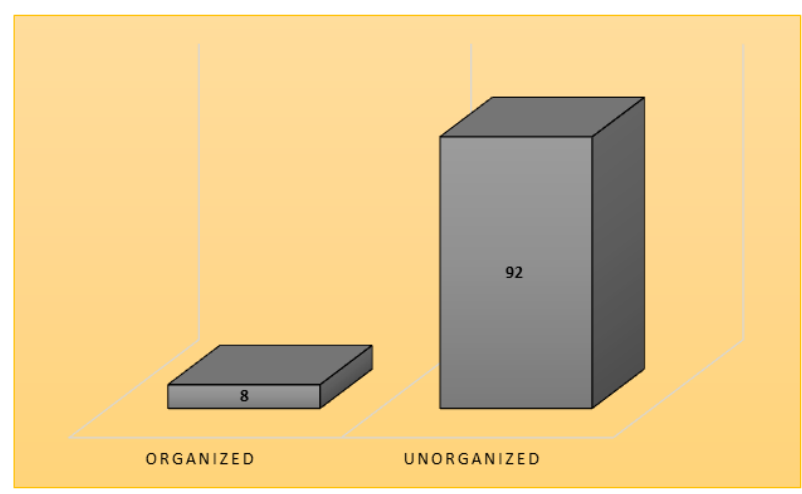

Fig-1: Type of Retail

Retailing in India has achieved significant development in the organized industry since the modernization of our national economy, which started in the early 1990s. The retail sector in India is said to have been decentralized with about around 8 per cent of the organized business, which means that only 8 per cent of retailers are licensed under the Regulators and Licensing. The remainder of the industry is unorganized. It is therefore seen as a great chance for the future of organized retail firms to grow and develop in India.

\section{Implementation of HRM organized retail}

Selection: Selections are predicated on discussion groups and interviews. Some retailers are taking an entrance test followed by a group conversation and a neuropsychological evaluation.

Employee Discipline: It is a tool for managing to correct the actions of employees.

Compensation: is the cost of services performed by a worker to an organization. Compensation can directly or indirectly reward me and may inspire workers at all levels.

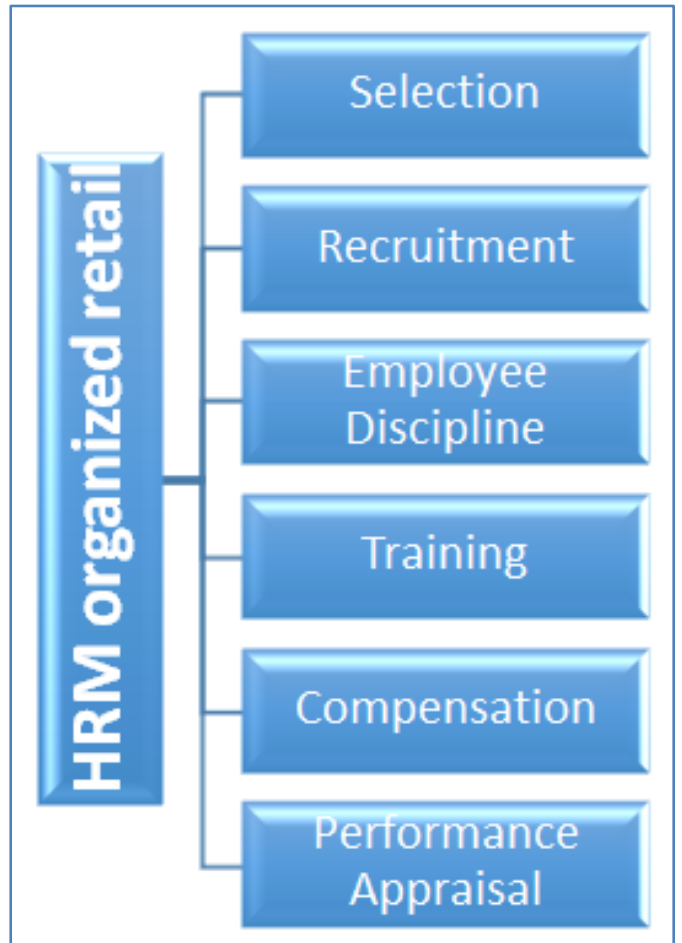

Fig-2: HRM in Organized Retail

Training: Retail sector is finally taking form in India and is recording fast growth. As organized retail is rising exponentially, the procurement of trained human resources for retail is a major challenge. The depth of talent is small so there is a huge market for trained and qualified experts in this sector with the introduction of large retailers into the market.

Recruitment: Depends on the size of either the proportion of vacant positions, or if it is a new warehouse, the hiring of the campus is carried out or the hiring is carried out by hirers and professionals. For factory floor sales necessity, the ad is published in local newsletters.

\section{Human resource obstacles in retail}

Lack of formal education: Since there is a shortage of structured vocational institutions where learners can be taught, most retailers in India rely through in-house training or on meeting their training requirements with limited institutions.

Warning of poaching: Employee theft is also very common across both organized and unorganized retail sectors. Skilled talent is limited in this sector and, as something else, recruiting competitors ' employees by providing them higher salaries is a quite easy choice. 


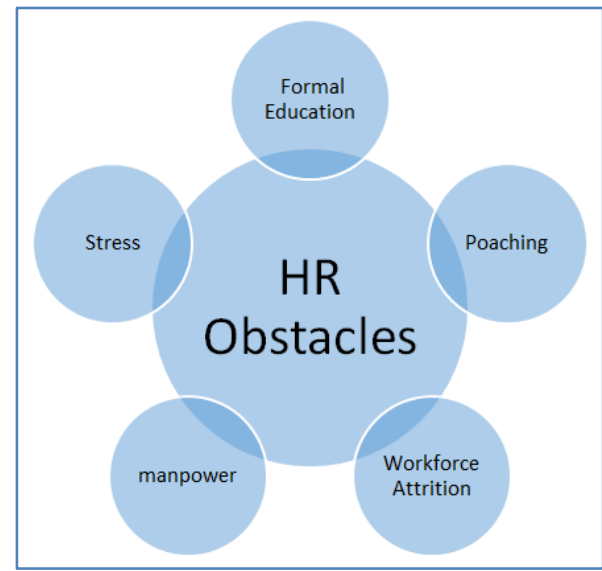

Fig-3: Human Resource Obstacles in Retail Sector

Attrition: There appears to become a high rate of turnover in the retail industry, which is almost $40 \%$ according to a new study.

Manpower: Organized retailing is a huge, power-driven business that employs a big pool of workers. Furthermore, there is a massive shortage of skilled retailers. It can be explained by the fact that retail has not been known to be a popular occupation in India, since very few retail training courses have taken place a few years ago.

\section{CONCLUSION AND RECOMMENDATION}

Human resource management practices (HRMP) are essential to the development and growth of business or industry. Such activities have also changed significantly in the retail industry. Retailers, particularly organized companies, are now putting stronger focus on HRM practices that include recruiting, choice, performance management, recruitment and retention, rewards, professional development, etc. In addition to this, the sector faces a number of challenges related to its human resources, such as lack of skills, lack of practical training in retail, depletion of the workforce, danger of poaching and a complex human capital climate. This suggests that HRM activities in the regulated retail sector need more focus in the immediate future to make it fairer.

Indian retailers require innovative $\mathrm{HR}$ strategies to handle a large workforce in a competitive market to improve the skill and recruitment of their workers. Alluring salaries and bonuses should be given to workers which also include either direct (salaries, commissions and bonuses) and indirect benefits (paid vacations, health and life insurance and retirement schemes). Many businesses are looking for too little ability. Retailers must preserve their trust in the overall job market by presenting their strengths in a way that separates the business from the competition.

\section{REFERENCES}

1. Bhaskar, N. (2012). Human Resource Management Practices in Organized Retailing: A Study of Select Retailers in Warangal District. Asian Journal of Research in Business Economics and Management, 2(6), 77-89.

2. HR Management in Retail. (2010). Retrieved from http://ckchinmayaprasad.blogspot.in/2010/06/hrmanagement-in-retail.html.

3. Karrupasamy, R., \& Kumar, N.R. (2014). Human Resource Practices in Organized Retailing-A Study of Selected Retailers. International Journal of Engineering and Management Sciences, 5(1), 1721.

4. Mehta, A.P., \& Mehta, R. (2013). Managing Human Resource in Retail Sector- An Upcoming Challenge. International Journal of Scientific Research, 2(5), 374-376.

5. Reddy, D.M., \& Chandra, S. (2011). Human Resource Management Practices in Organized Retailing: A Study of Select Retailers. International Journal of Multidisciplinary Research, 1(8), 523534.'

6. Reddy, D.M., \& Chandra, S. (2011). Human Resource Management Practices in Organized Retailing: A Study of Select Retailers. International Journal of Multidisciplinary Research, 1(8), 523534.

7. Vedamani, G.G. (2009). Evolution of Organized Retailing in India: A Study of Apparel Industry. Symbiosis International University, Pune.

8. http://wfnetwork.bc.edu/

9. http://www.naukrihub.com/

10. Performance Management Systems, By R. K. Sahu

11. Human Resource Management, By K. Aswathappa; KPMG Report. (2006). Indian Retail on the Fast Track: Bridging the Capability Gaps. 